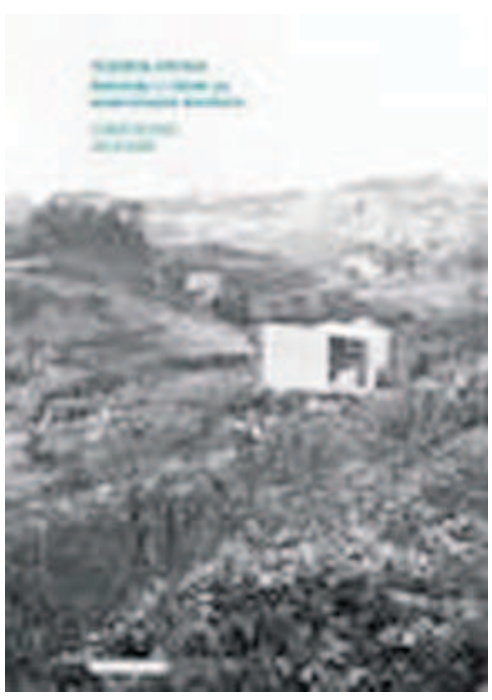

VILANOVA ARTIGAS:

HABITAÇÃO E CIDADE NA MODERNIZAÇÃO BRASILEIRA

MEDRANO, LEANDRO; RECAMÁN, Luiz. Campinas: Editora Unicamp e

FUNCAMP, 2013.

ISBN: 97885268 I050I

Mônica Junqueira de Camargo

\title{
A Arquitetura De Vilanova artigas E A CONSTRUÇÃO DA CIDADE MODERNA
}

Os estudos das últimas décadas sobre a arquitetura de João Vilanova Artigas vêm ampliando largamente a compreensão de seus trabalhos, e reforçam cada vez mais a importância de sua contribuição à cultura arquitetônica. A investigação dos arquitetos professores Leandro Medrano e Luiz Recamán traz uma leitura instigante da relação entre seus projetos residenciais dos anos 1940 a 1960 e a modernização da cidade de São Paulo, leitura que muito provavelmente despertará acirrados debates, uma vez que aponta para as contradições existentes entre a arquitetura moderna e a conformação das cidades brasileiras.

Entendendo, como recuo, aquilo que é defendido como um avanço, os autores problematizam algumas versões consensuais da obra de Artigas - no que diz respeito às especulações urbanas que seus projetos sugerem, ou ao significado da ênfase construtiva de suas ousadias estruturais, assumidas como constituidoras da escola paulista - , ou seja, o legado de Artigas que ainda repercute na produção contemporânea.

A trajetória traçada pelos autores tem início no desafio de se enfrentar a condição territorial adversa aos princípios da cidade moderna, recuperando o conflito gerado entre a rua entendida como vazio da composição arquitetônica, e como espaço público, e terá seu ápice na total dissociação entre o ambiente interno das casas e o território a que pertence.

De uma produção mais ampla (vale lembrar que a maioria dos projetos concebidos até 1950 era de inspiração acadêmica), os autores selecionaram cinco, como gêneses do conceito do vazio enquanto elemento de superação da lógica de ocupação territorial e de centralidade do espaço doméstico, a saber: os 
projetos de suas duas residências (1942 e 1949); a casa Czapski (1949); a casa Heitor de Andrade, em Santos (1949); e a casa D’Estefani (1950). O vazio, segundo a leitura de Medrano e Recamán, é identificável a partir da implantação, que nega o padrão e incorpora o resíduo territorial à composição arquitetônica, que em seguida se incorpora ao espaço doméstico, como elo entre volumes, e é depois incorporado à unidade volumétrica, ganha gradualmente preponderância, até assumir a condição de estruturador espacial do programa. Condição essa que inibe a expansão volumétrica, e consequentemente sua reprodutibilidade, impedindo qualquer possibilidade de desdobramento para a constituição do espaço urbano.

Nos projetos analisados na sequência: Olga Baeta, Casa dos Triângulos, Taques Bittencourt 2, são esclarecidas as estratégias arquitetônicas que, atreladas ao conceito do vazio, sublimam o entorno indesejado, tanto sob a ótica compositiva, como construtiva: a opção pelo prima, a eliminação da fachada, entendida como parte do processo de independência da unidade arquitetônica em relação ao mundo social, e a unificação dos diferentes elementos construtivos - estrutura, vedação, cobertura, piso etc. A objetividade estrutural do concreto forte referência da escola paulista, ainda hoje recorrente na produção contemporânea - para os autores, não remete às questões tecnoconstrutiva e conceitual, e sim a uma operação retórica. A investigação conclui que a tipologia - criada a partir da trajetória projetual, da unidade unifamiliar aberta a um vazio exterior, ao enclausuramento definitivo do interior - era incompatível, devido a suas próprias premissas espaciais formais - o volume fechado -, com o desenvolvimento de novos padrões urbanos compatíveis com a modernização da cidade de São Paulo nos anos 1950. A formulação ideológica da grande cobertura apoiada em uma estrutura de desenho sofisticado, a abrigar o espaço doméstico entendido como laboratório de processamento das questões não só do espaço e da cidade, mas da sociedade e de sua transformação, não se desdobra em cidade: "da casa isolada não resulta hipótese urbana além da realidade a que se submete" (p. 109). O paradoxo, segundo os autores, se torna mais evidente, quando esse modelo é aplicado em propostas de áreas inteiramente novas, sem estrutura territorial pré-definida, como no plano para Brasília, onde se reproduz, em escala urbana, esse ideal de espaço, ou no Conjunto Zezinho Magalhães, onde o espaço coletivo é o resíduo da multiplicação dos blocos.

Ainda que essa tipologia residencial não seja compatível com a criação de um padrão urbano moderno, como demonstram Medrano \& Recamán, é facilmente identificável que ela suscitou, a partir de então, a especulação do sentido de urbanidade, sobretudo nas obras públicas, com resultados dos mais variados. O atraso da construção civil brasileira, que inviabilizaria a conformação da cidade moderna, pode ser rebatido pela expressiva quantidade de arranhacéus construída nas principais capitais brasileiras, nas décadas de 1920 e 1930. O edifício Louveira (1946) de Vilanova Artigas, comentado rapidamente em uma nota de rodapé ( $p .31$ ), seria um projeto interessantíssimo a ser explorado nessa análise, tanto do ponto de vista construtivo, como compositivo da cidade brasileira moderna, uma vez que propõe, a partir da unidade habitacional, nova forma de ocupação territorial, integrada ao espaço tradicional.

Do mesmo modo, o rebatimento desse legado de Artigas na produção contemporânea, ilustrado pelos autores com o artigo de Roberto Segre publicado 
na revista AV Monografias, n. 139, 2009, talvez não seja o melhor exemplo. Primeiro, porque, na análise de Segre, o arquiteto de referência é Paulo Mendes da Rocha, que, por sua vez, teria se alimentado na fonte do Artigas, e não há como desconsiderar a autonomia de Mendes da Rocha. Segundo, a análise concentra-se entre 1940 e 1960, obliterando a trajetória subsequente do próprio arquiteto - quando projetou a maior parte de suas obras públicas, nas quais o significado das ideias levantadas por Medrano \& Recamán podem ser mais bem aferidas - e o contexto, que passou por mudanças de toda ordem, que permitiram outras assimilações desse legado.

Além de a leitura inédita que os autores promovem ser, per si, uma contribuição à crítica da arquitetura, o método de análise a partir do projeto traz ao debate outros elementos que a historiografia até então não considerou, ampliando as possibilidades de interpretação desse legado criteriosamente resgatado pelos autores.

\section{Mônica Junqueira de Camargo}

Arquiteta, professora livre-docente da FAUUSP, na área de arquitetura moderna e contemporânea, diretora do Centro de Preservação Cultural da USP (CPC).

Departamento de História da Arquitetura e Estética do Projeto

Rua do Lago, 876, Butantã

05508-080 - São Paulo, SP, Brasil

(11) 3091-4555

junqueira.monica@usp.br 